\title{
The importance of empirical research on public perceptions and attitudes towards forests for participatory policy development
}

\author{
Working Paper \\ Author(s): \\ Zimmermann, Willi; Schmithüsen, Franz Josef \\ Publication date: \\ 2001 \\ Permanent link: \\ https://doi.org/10.3929/ethz-a-005705692
}

Rights / license:

In Copyright - Non-Commercial Use Permitted

Originally published in:

Working papers. International series 2001(2) 


\section{Working Papers \\ International Series}

Forest Policy and Forest Economics

Department of Forest Sciences

The Importance of Empirical Research on Public Perceptions and Attitudes towards Forests for Participatory Policy Development

Willi Zimmermann and Franz Schmithüsen

Published in: Price, M.; Butt, N., Eds., 2000:

Forests in Sustainable Mountain Development.

A State of Knowledge Report for 2000.

IUFRO Research Series 5: 176-181; CAB International, Wallingford, U. K.

Zurich 2001 
Working Papers International Series Forest Policy and Forest Economics

\section{Series Editor}

Prof. Dr. Franz Schmithüsen

Department Forest Sciences

Swiss Federal Institute of Technology, ETH

Zurich / Switzerland

E-mail: Schmithuesen@fowi.ethz.ch 


\title{
The Importance of Empirical Research on Public Perceptions and Attitudes towards Forests for Participatory Policy Development
}

\author{
Willi Zimmermann and Franz Schmithüsen
}

\section{The Changing Context of Public Intervention Regulating Forest Conservation and Development}

Forest have always had and continue to have a great importance for people living in mountainous areas. They supply construction timber and firewood; they are needed for subsistence in providing a wide range of forest products; and they are a complementary space for agriculture and pasture which is used in integrated land management and production systems. As a protective environment, many forests have been declared protection forests by local customs and regulations, with strict rules determining use and management practices. At the same time, mountain forests have been valuable resources in many countries as sources of energy and raw material for expanding cities and industries. In most places the social meaning of mountain forests has fundamentally changed during recent decades (FAO/ECE/ILO 1998).

While the basic requirements of people and the economy have remained the same, the weight of the multiple demands on forests has changed as traditional wants are overlapped by new demands. With an increasingly mobile population and the rapid expansion of infrastructure, mountainous regions have become important recreational areas attracting large numbers of visitors. With the expansion of settlements, new roads and railway communications and the installation of tourist facilities, the importance of the protective role of the forest has become more important. Yet, in regions now being intensively developed there are still large forest areas with a rich fauna and flora, of particular interest for nature conservation.

The economic and social importance of forests, in both regional and national contexts, has led to a network of central steering processes and formal regulations (Schmithüsen, 1995). For instance, in the European countries with a considerable proportion of forests in the Alps, forest laws contain strict provisions regarding the protection of the mountain areas in the interest of the country as a whole. The laws were 
designed during the 19th century; a small group of forest experts had recognized the negative consequences of over-exploitation and an indiscriminate reduction of the forest cover as a national problem, and successfully put conservation on the political agenda. Political decisions, taken by parliaments and governments - with representatives not necessarily from the mountains - were subsequently adopted; the new laws were implemented by small but well-structured national and regional forest services.

Public interventions are based, to a large extent, on the use of traditional policy instruments, and rely on the institutional arrangements used to solve forest problems in the past. Regulative and centrally geared public interventions continue to dominate government forest policies in many countries. This approach does not reflect changes in political decision-making processes: new trends concerning deregulation and less government, decentralization of public competence, the use of incentive instruments, bottom-up approaches instead of authoritative top-down regulation, increased participatory and co-operative management practices, and the involvement of minorities.

The call for more participation of those who are affected by specific policy measures has become one of the fundamental postulates of the post-Rio process. It is an essential requirement of international legal instruments, such as the Convention on Biological Diversity, as well as of regional agreements (e.g., the recent Lisbon declaration of the European Ministerial Conference on Forests). Involvement of the public, usergroups, and a wide range of non-governmental organizations is a key factor in economically and socially sustainable development (Glück et al., 1999). Public policies can no longer be decided upon without the participation of those involved in implementing the envisaged policy measures. What matters are their interests and opinions - not only the judgements of professional experts and competent administrations.

\section{Research on Public Perceptions of Forests and Forestry Practices}

Empirical social research on public perceptions and attitudes towards forests has become increasingly important. The resulting information is necessary for the integration of the opinions and demands of the relevant policy actors into political planning and decisionmaking processes at an early stage. Knowledge obtained from such research is valuable for both policy formulation and implementation; it helps to identify political problems 
before they lead to larger confrontations, to open the agenda-setting process for new political issues, to decide on alternative instruments, and to improve the effectiveness and efficiency of policy implementation strategies.

A considerable amount of research into the relationships between people and forests has been undertaken, for instance in Europe (Schmithüsen et al., 1997; Terrasson, 1998; Wiersum, 1998). Most of these studies focus on forest management issues and are limited to local conditions. In other regions, studies on indigenous knowledge and sociocultural aspects of trees and forests contain valuable information on local perceptions and attitudes (Seeland, 1997, Croll, Parkin 1992, Warren et al. 1995). Research gives a detailed picture of the multiple and changing social demands on forests, and sustainable forest practices, and local resources management (Price, 1990; Dove, Carpenter 1992, Parolini, 1995, Poffenberger, McGean 1996). However, empirical information on actual demands as expressed by public perceptions and attitudes, both in Europe and in other parts of the world, has been rather scarce.

The Swiss research project 'Public Perception of Mountain Forestry and Forest Policy', initiated in 1994, specifically analysed the social meaning of forests in mountain regions (Zimmermann, 1996; Schmithüsen et al., 1999). A cross-sectional survey was designed to assess attitudes towards, and opinions on, forests, forestry, and forest policy. A questionnaire was mailed randomly to members of the voting mountain population and two members each of local government authorities. In total, 2,160 individuals and 72 communal councillors were selected. Within two months, more than 650 questionnaires were returned: 40 from members of local governments and over 600 from the public. The return rate was approximately $29 \%$ for the voting population and $60 \%$ for respondents from local governments.

A significant finding was that among the terms spontaneously associated with forest, recreation and nature were by far the most frequently listed by the Alpine population (Zimmermann et al., 1998). Of equal importance was the almost unanimous response that forest tending is regarded by the public as the most important activity of forest owners. These three elements - recreation, nature, forest tending - will have considerable weight in adapting (and implementing) public forest policies to changing social demands in the mountain regions of Switzerland. The Federal Forest Agency has 
shown marked interest in the empirical data, and has subsequently launched a representative survey of the whole population in order to obtain more reliable information on public attitudes towards forests and forestry.

\section{Relevance of Empirical Results on Perceptions and Attitudes towards Forests for Policy Development and Implementation}

Information gained from empirical perception research is relevant in every stage of political processes (Wild-Eck and Gasser, 1998). During the phase in which a policy issue is articulated and defined, the results of surveys indicate whether people associate relevant social problems with mountain forests. A high level of perceived actual and potential conflicts demonstrates the urgency for political arbitration and possibly intervention; a low level of may be interpreted as public policies finding acceptance and satisfaction - there is little pressure for new political actions. Perception research can thus be used as part of an early warning system that allows the detection of weaknesses of the political framework regulating sustainable forest use. Wangchuk (1998) provides an example of this type of social monitoring, using a large amount of data on social and institutional performance related to mountain forests in Bhutan. The results offer an opportunity to compare the effectiveness of policy measures between countries with comparable conditions, and alternative governmental and communal problem-solving approaches.

Formulating policy programmes with specific objectives, measures and instruments leads to new or amended legislation. Responding to changing social demands, public policies and legislation are in the process of revision in many European countries (FAO/ECE/ILO, 1998, Schmithüsen, 1999). Among the key issues are the need to provide both an institutional basis for greater participation of the actors at whom new policy requirements are directed, and more effective process-steering instruments for cooperation between state agencies and non-governmental organisations (NGOs).

The principle of social sustainability, which is the underlying rationale for such changes, is of particular relevance for people living in mountain areas. They depend to a larger extent on the forest environment and have a legitimate interest in articulating their requirements in determining public intervention and management practices. Their opinions and demands are constitutive elements of democratic policy formulation 
processes that allow the proposal of acceptable management options, social benefits, and the financing of necessary measures for sustainable mountain development. The Swiss project on public perceptions and attitudes has shown, for instance, that the opinion - with regard to important forest policy issues - of the majority of people may differ from that of their political elected representatives. There may also be discrepancies between public attitudes and the demands of NGOs. It remains open to what extent the demands of such groups are based on internal participatory processes, as opposed to the assessment of opinion leaders.

Representative empirical inquiries provide valuable information for public decisions, with far reaching consequences for local populations. The results of studies on local perceptions and attitudes, if interpreted and used appropriately, are a complementary element in the formulation of policy programmes that do not substitute, but challenge, the knowledge and judgements of experts and politicians. As mountain development offers a wide range of options for management and conservation practices, public surveys are significant in the development of new participatory forest policies. This refers to the definition of policy goals (e.g., the amount and distribution of forest cover) as well as to appropriate forms of public intervention combining mechanisms for regulation, information dissemination, and incentive provision.

While policy programmes usually leave implementation to the public administration, a differentiated approach is necessary for popular acceptance; research into local attitudes towards forests and forestry provides relevant information regarding the extent to which a national approach can respect regional particularities. It indicates whether complementary measures would be useful in mountain regions, and helps to realistically assess the potential involvement of the various actors. This is particularly pertinent to forest management planning which considers population requirements at both local and regional levels. Simple and standardized public opinion surveys linked to planning processes promote both the identification of a broad range of options, and public acceptance for the proposed management practices. Surveys within public administrations can help develop better solutions, and initiate learning processes among civil servants. 


\section{Perspectives}

Research projects must be undertaken in accordance with consistent scientific criteria such as representation, reliability, validity, precision and sensitivity (Jensen and Koch, 1998). This requires a sound knowledge of empirical quantitative and qualitative research methods, and collaboration among researchers from several disciplines. An interdisciplinary research design which combines forestry expertise with inputs from the relevant social sciences is necessary to obtain results that can be used in policy development and forest management planning (Wild-Eck and Zimmermann, 2000).

The problems related to mountain forests must be analysed and solved in a larger geographical, economic and cultural context. This changes the institutional framework in which forest-related political decision-making processes occur; many decisions are part of more complex land management and rural development options. Regional development planning, nature and landscape conservation programmes, and multi-sectoral economic and social programmes are both institutional outputs and the reference for public interventions in forestry. An integrative approach to land management cannot be successful without the understanding and consent of the population as a whole. Forest issues become part of a much broader network of interested actors and various policy arenas at different levels. To act successfully in such a situation requires flexibility and awareness of public opinion and understanding of the multiple demands of the population. An interdisciplinary approach in research and teaching helps to develop the necessary capabilities.

A policy domain in which research on perceptions and attitudes is of particular relevance is evaluation. This refers in particular to the role of forest owners: the principal addressees of forest policy measures. Their attitudes and immediate reactions decide, to a large extent, whether instruments of public forest policy provide positive or negative results in mountain forest management. The central role of forest owners has led to a new European Union (EU) research project. Within the EU's fifth framework programme for research on technological development and demonstration (RTD), and as part of the component 'Quality of life and management of living resources' a project to investigate the requirements and perspectives of forest owners has been launched. Among the 11 
participating countries, several have a considerable part of their forests in mountain regions. The results of the project will furnish information on a comparative basis allowing the evaluation of specific conditions of mountain forest management and the assessment of differences in perceptions between land owners, non-governmental organisations and public services.

Due to changes in social values and new political concepts, public perception research will continue to gain importance in public policy development. Empirical research is a valuable source of information for the formulation and implementation of many sectoral and cross-sectoral policies. The broadening objectives, as well as new instruments of public forest policies, provide an institutional framework that requires a more profound understanding of how forest and forestry development are perceived. The same applies to management planning, which, especially in mountain regions, refers to managerial aspects as well as to comprehensive rural development issues. The move of public services towards more demand and output-orientated policies emphasises the need for regular information on public opinion towards forests and forestry. 


\section{References}

Croll, E.; Parkin, D (eds.) 1992: Bush Base, Forest Farm. Culture, Environment and Development. London/New York: Routledge.

Dove, M, R.; Carpenter C. (eds.) 1992: Sociology of Natural Resources in Pakistan and Adjoining Countries. Lahore: Vanguard

FAO/ECE/ILO (eds), 1998: People, Forests and Sustainability - Social Elements of Sustainable Forest Management in Europe. International Labour Office, Sectoral Working Paper, Geneva, 213 pp.

Glück, P.; Oesten, G.; Schanz, H.; Volz, K.-R. (eds.) 1999: Formulation and Implementation of National Forest Programmes. Volume 1: Theoretical Aspects. EFI Proceedings Nr.30, 296 pp.

Jensen, F.S.; Koch, N.E., 1998: Measuring Forest Preferences of the Population; a Danish Approach. In: Terrason, D. (ed.) 1998: Public Perception and Attitudes of Forest Owners towards Forest in Europe. Cemagref Editions, Antony cedex, France, pp. 39-82

Parolini, J.D., 1995: Zur Geschichte der Waldnutzung im Gebiet des heutigen Schweizerischen Nationalparks. Diss ETH Zürich Nr. 11‘187, 227 pp.

Poffenberger, M.; McGean, B. (eds.) 1996: Village Voices, Forest Choices. Joint Forest Management in India. Delhi: Oxford University Press

Price, M.F., 1990: Mountain Forests as Common-Property Resources - Management Policies and their Outcomes in the Colorado Rockies and the Swiss Alps. Forstwissenschaftliche Beiträge der Professur Forstpolitik und Forstökonomie der ETH Zürich, Vol.9, 251 pp.

Schmithüsen, F. (1995): Evolution of Conservation Policies and their Impact on Forest Policy Development: The Example of Switzerland. The Commonwealth Forestry Review: Special Issue on Forestry and Nature Conservation; Vol. 74, 1: 45-50.

Schmithüsen, F.; Kazemi, Y.; Seeland, K. (1997): Perceptions and Attitudes of the Population towards Forests and their Social Benefits. Social Origins and Research Topics of Studies conducted in Germany, Austria and Switzerland between 1960 and 1995. IUFRO, Vienna; Occasional Paper Nr.7, 64 pp.

Schmithüsen, F., 1999: The Expanding Framework of Law and Public Policies Governing Sustainable Uses and Management in European Forests., Beiträge der Professur Forstpolitik und Forstökonomie, Vol. 21, 1999, pp.1-30;.Swiss Federal Institute of Technology (ETH), Zurich.

Schmithüsen, F.; Wild-Eck, St.; Zimmermann, W., 1999: Wissen, Einstellungen sowie Zukunftsperspektiven der Bevölkerung im Berggebiet zum Wald, zur Forstwirtschaft und zur Forstpolitik. Ergebnisse einer Befragung in sechs schweizerischen Gebirgskantonen. Abschlussbericht zum Forschungsprojekt COST E 3; Professur Forstpolitik und Forstökonomie, Swiss Federal Institute of Technology (ETH), Zurich.

Seeland, K. ed., 1997: Nature is Culture -Indigenous Knowledge and Socio-cultural Aspects of Trees and Forests in non-European Cultures. Intermediate Technology Publications, London. 152 pp. 
Terrasson, D. (ed.), 1998: Public Perception and Attitudes of Forest Owners towards Forest in Europe. CEMAGREF Editions, Antony Cedex, France, 243 pp.

Wangchuck, S., 1998: Local Perceptions and Indigenous Institutions as Forms of Social Performance for Sustainable Forest Management in Bhutan. Forstwissen-schaftliche Beiträge der Professur Forstpolitik und Forstökonomie der ETH Zürich, Vol.20, 178 pp.

Warren, D. M.; Slikkerveer, L. J.; Brokensha, D. (eds.) 1995: The Cultural Dimension of Development. Indigenous Knowledge Systems. London: Intermediate Technology Publications

Wiersum, F. (ed.), 1998: Public Perception and Attitudes of Forest Owners toward Forest and Forestry in Europe. Hinkeloord Report 24; Sub-Department of Forestry, Agricultural University of Wageningen, $137 \mathrm{pp}$.

Wild-Eck, St.; Gasser, G., 1998: La Portée des Enquêtes dans le domaine de la Politique Forestière. In: Schweizerische Zeitschrift für Forstwesen, 149(6), 245-262.

Wild-Eck, St.; Zimmermann, W., 2000: COST- und Monitoring-Projekt: Zwei neue forstliche Meinungsumfragen im Vergleich. Schweizerische Zeitschrift für Forstwesen; forthcoming.

Zimmermann, W., 1996: Public Perception of Mountain Forestry and Forest Policy. In: Glück, P.; Weiss, G. (eds.) Forestry in the Context of Rural Development - Future Research Needs; EFI Proceedings $N^{\circ} 15$, p. 107-120.

Zimmermann, W.; Schmithüsen; F.; Wild-Eck, St., 1998: Main Findings and Policy Implications from the Research Project Pubic Perceptions of Mountain Forests in Switzerland. In: Wiersum, K.F. (ed.), 1998: Public Perception and Attitudes of Forest Owners towards Forest and Forestry in Europe. Hinkeloord Report 24: 47-59; SubDepartment of Forestry, Agricultural University Wageningen. 
WORKING PAPERS INTERNATIONAL SERIES FOREST POLICY AND FOREST ECONOMICS

Series Editor: Prof. Dr. Franz Schmithüsen, Department of Forest Sciences, Swiss Federal Institute of Technology (ETH), Zurich/Switzerland

01/2 Zimmermann Willi / Schmithuesen Franz

The Importance of Empirical Research on Public Perceptions and Attitudes towards Forests for Participatory Development.

Published in: Price, M.; Butt, N., Eds., 2000: Forests in Sustainable Mountain

Development - A State of Knowledge Report for 2000. IUFRO Research Series 5:

176-181; CAB International, Wallingford, U. K. (9 pages)

01/1 Schmithuesen Franz / Wild-Eck Stephan

Uses and Perceptions of Forests by People Living in Urban Areas: Findings from

Selected Empirical Studies.

Published in Forstwissenschaftliches Centralblatt 119 (2000): 395-408. (24 pages)

00/8 Schmithüsen Franz

Communal Forest Tenure in Switzerland: Towards Co-Financing Forest

Management Systems. (15 pages)

Published in: Schmithüsen, F.; Herbst, P.; Le Master, D.C., Eds. 2000: Forging a New Framework for Sustainable Forestry - Recent Developments in European Forest Law. IUFRO World Series Volume 10: 315-326. International Union of Forestry Research Organisations, IUFRO Secretariat, Vienna

00/7 Cirelli Maria-Teresa / Schmithüsen Franz

Tendencias del Derecho Forestal: Europa Occidental. (40 pages)

Estudio Legislativo de la FAO en linea No 10, Junio 2000, Roma

http://www.fao.org/Legal/default.htm (

00/6 Schmithüsen Franz / Zimmermann Willi

The New Federal Swiss Forest Legislation: Constitutional Competencies, Objectives, Instruments and Policy Actors. (20 pages)

Published in: Schmithüsen, F.; Herbst, P.; Le Master, D.C., Eds. 2000: Forging a New Framework for Sustainable Forestry - Recent Developments in European Forest Law. IUFRO World Series Volume 10: 298-314. International Union of Forestry Research Organisations, IUFRO Secretariat, Vienna

00/5 Schmithuesen Franz / Iselin Georg

Bibliography 1984-2000 of Contributions from the IUFRO Group Forest Law and

Environmental Legislation (35 pages)

00/4 Cirelli Maria-Teresa / Schmithüsen Franz

Tendances du droit forestier: Europe Occidentale. Etude juridique en ligne (2000) \# 10; Rome, FAO. (37 pages)

00/3 Seeland Klaus / Schmithüsen Franz

Forest Use and Management in the Wider Himalayan Context - Selected Papers.

Published in Man in the Forest - Local Knowledge and Sustainable Management of

Forests and Natural Resources in Tribal Communities in India, 1-47; New Dehli,

D.K. Printworld. (39 pages) 
00/2 Schmithuesen Franz

Percevoir la forêt et la gestion forestière. In: Arnould, P.; Hotyat, M., (edt.), 1999:

Forêts et filières bois de l’hémisphère nord. Ann. Géo, Nr. 609-610 (1999): 479-

508; Paris, Armand Colin. (27 pages)

00/1 Cirelli Maria-Theresa / Schmithuesen Franz

Trends in Forestry Legislation: Western Europe. Legislative Study Online (2000), No 10; Rome, FAO. (35 pages)

\section{9/5 Rocek Ivan}

Les opinions des propriétaires forestiers - Résultats d'une enquête en République

Tchèque. (50 pages)

\section{9/4 Schmithuesen Franz}

The Expanding Framework of Law and Public Policies, Governing Sustainable Uses and Management in European Forests. Published in Experiences with New Forest and Environmental Laws in European Countries with Economics in Transition; Forstwissenschaftliche Beiträge Forstpolitik und Forstökonomie, Vol 21, p.1-30; ETH Zürich, 1999. (37 pages)

99/3 Zimmermann Willi / Schmithuesen Franz / Wild-Eck Stephan

Main Findings and Policy Implications from the Research Project Public

Perceptions of Mountain Forests in Switzerland. Published in Wiersum, F. (ed),

1998: Public Perceptions and Attitudes of Forest Owners Towards Forest and

Forestry in Europe, Hinkeloord Report 24: 47-59; Agricultural University

Wageningen. (15 pages)

99/2 Schmithuesen Franz / Iselin Georg

Bibliography 1984-1999 of the IUFRO Research Group Forest Law and

Environmental Legislation. (27 pages)

99/1 Schmithüsen Franz / Zimmermann Willi

Forestry Case Study Switzerland. In: Pelkonen, P.; Pitkänen, A.; Schmidt, P.; Oesten, G.; Piussi, P.; Rojas, E.; eds., 1999: Forestry in Changing Societies in Europe - Information for Teaching Module Silva Network Part II, pp. 415-441; University Press, Joensuu/Finland. (25 pages)

98/2 Eggermont Katrien / Schmithuesen Franz

WWF International as a Policy Actor and its Involvement in Promoting Forest Conservation.

Results from a Diploma Thesis jointly undertaken by the Chair Forest Policy and Forest Economics of the ETH and the Laboratory for Forest, Nature and Landscape Research of the Catholic University Leuven. (52 pages)

98/1 Schmithuesen Franz / Kazemi Yves / Seeland Klaus

Actitudes de la Población ante el Bosque y sus Prestaciones Sociales (27 pages).

In: Agricultura y Sociedad Nr. 85 (1998) 1: 43-66, Madrid

97/5 Schmithuesen Franz / Seeland Klaus / Wild Stephan / Zimmermann Willi:

Voluntary Papers presented at the XI World Forestry Congress held in Antalya, Turkey, October 1997 (33 pages) 